\title{
Efektifitas Metode Pembelajaran Field Trip Pendekatan DFC Mengembangkan Entrepreneurial Leadership Anak Petani Garam
}

\author{
Siti Fadjryana Fitroh¹, Dewi Mayangsari², Ratna Nila Puspitasari ${ }^{3}$ \\ 1,2,3 Program Studi PG PAUD Fakultas Ilmu Pendiikan Universitas Trunojoyo Madura, Jl. Raya Telang, Kamal, \\ Bangkalan, Madura 69162 Indonesia
}

\begin{tabular}{|c|c|}
\hline INFO ARTIKEL & Abstract \\
\hline \begin{tabular}{ll}
\multicolumn{3}{l}{ Sejarah Artikel: } \\
Diterima $\quad:$ \\
Diperbaiki & $: 6$ Februari 2019 \\
Disetujui & $: 6$ Februari 2019
\end{tabular} & \multirow[b]{2}{*}{$\begin{array}{l}\text { Experience is part of an important aspect of learning, besides that it needs to } \\
\text { be noted that the characteristics of early childhood, the main one is high } \\
\text { curiosity supported by imagination. To be able to facilitate it all is needed to } \\
\text { provide the right stimulus through the methods and approaches integrated in } \\
\text { learning. The form of learning activities is also a determining factor, which is } \\
\text { clearly all done in the principle of fun learning and that is in entrepreneurial } \\
\text { activities. In every learning that is applied to early childhood it is important to } \\
\text { be formed consistently both at home, school and the environment around the } \\
\text { residence. In learning also aims at the formation of personal character that is } \\
\text { having the soul of leadership. By having these characters, the hope is that the } \\
\text { child can later become the successor to the generation that has been tradition } \\
\text { in Lembung Village, Galis Subdistrict, Pamekasan Regency, namely Garam } \\
\text { entrepreneurs. However, all of that must go through a process, if you want the } \\
\text { right end. This study involved } 15 \text { group B students at the PKK Lembung } \\
\text { Kindergarten, using qualitative methods with sources of data on observation, } \\
\text { interviews and documentation. The purpose of this study is to look at the } \\
\text { effectiveness of learning using field trip learning methods or tourism works } \\
\text { integrated with the DFC approach to salt farmers. The field trip method } \\
\text { integrated with the DFC approach in entrepreneurial activities has the aim } \\
\text { that the salt farmer's children who already have entrepreneurial leadership } \\
\text { provision have more courage, independence, skills so as to minimize failures in } \\
\text { themselves, not easily discouraged, continue to struggle and be optimistic. }\end{array}$} \\
\hline \multirow[t]{2}{*}{$\begin{array}{l}\text { Keywords: } \\
\text { Entrepreneurial Leadership; field trip } \\
\text { learning method; Children of Salt } \\
\text { Farmers. }\end{array}$} & \\
\hline & Abstraks \\
\hline $\begin{array}{l}\text { Kata Kunci: } \\
\text { Entrepreneurial Leadership; } \\
\text { Metode Pembelajaran Field Trip; } \\
\text { Design For Change; Anak Petani } \\
\text { Garam. }\end{array}$ & \multirow{2}{*}{$\begin{array}{l}\text { Pengalaman merupakan bagian aspek penting dalam pembelajaran, } \\
\text { selain itu perlu diperhatikan karakteristik anak usia dini yang utama } \\
\text { yakni rasa ingin tahu yang tinggi didukung dengan imajinasi. Untuk } \\
\text { dapat memfasilitasi itu semua dibutuhkan pemberian stimulus yang } \\
\text { tepat lewatmetode dan pendekatan yang diintegrasikan dalam } \\
\text { pembelajaran.Bentuk kegiatan pembelajaran juga menjadi faktor } \\
\text { penentu, yang jelas semua dilakukan tetap dalam prinsip belajar } \\
\text { menyenangkan dan itu ada dalam kegiatan entrepreneurial.Di setiap } \\
\text { pembelajaranyang diterapkan pada anak usia dini penting dibentuk } \\
\text { secara konsisten baik di rumah, sekolah maupun lingkungan sekitar } \\
\text { tempat tinggal. Dalam pembelajaran juga bertujuanpada pembentukan } \\
\text { pribadi berkarakter yakni memiliki jiwa leadership.Dengan memiliki } \\
\text { karakter tersebut harapannya anak nantinya dapat menjadi penerus } \\
\text { usaha turun temurun yang sudah mentradisi di Desa Lembung }\end{array}$} \\
\hline DOI: & \\
\hline
\end{tabular}






\section{PENDAHULUAN}

Di zaman serba teknologi membuat kita harus peka dengan banyaknya perubahan.Sebagai seorang pendidik harusnya memiliki kesiapan cara memproduk anak didik, menyiapkan mereka peka zaman dan bisa menjadi individu yang mandiri menghadapi berbagai bentuk perubahan. Selain itu penidik harus mampu mengkonsep pembelajaran tetap berkesan menarik, menyenangkan dan masih dalam suasana pembelajaran yang mendidik. Namun, sebelum berbicara tentang pembelajaran coba kita sepakati bahwa pendidikan yang konsisten harus diterapkan sejak usia dini. Mengapa hal ini menjadi penting untuk ditanggapi karena masih banyak masyarakat menilai bahwa tidak begitu penting pendidikan usia dini, dimana masyarakat masih meminta anaknya cukup tinggal dirumah menghabiskan waktunya untuk bermain namun kurang terkonsep. Hal inilah yang membuat anak-anak usia dini banyak menghabiskan waktunya bermain dirumah dengan tidak berkonsep apalagi tidak ada pendampingan dari orangtua atau pengetahuan orangtua tentang pemberian stimulasi secara tepat kurang. Fenomena inilah membuat penting adanyapendidikan anak usia dini dan disepakati masyarakat.

Pendidikan untuk anak usia dini adalah sebuah proses membentuk diri anak diusia 0-6 tahun dapat tumbuh dan berkembang menjadi usia yang sangat produktif dalam mengembangkan segala macam potensi berdasarkan karakteristik yang dimiliki. Menurut Hartati (2005) menjelaskan bahwa karakteristik anak usia dini adalah 1) memiliki rasa ingin tahu yang besar, 2) memiliki pribadi yang unik, 3) suka berfantasi dan berimajinasi, 4) masa potensial untuk belajar, 5) memiliki sikap egosentris, 6) memiliki rentan daya konsentrasi yang pendek, 7) merupakan bagian dari mahluk sosial. Karakteristik diatas memberikan penjelasan bahwa potensi harus dapat berkembang maksimal.

Salah satu bentuk potensi yang dapat dikembangkan sejak usia dini adalah jiwa leadership. Pentingnya mengembangkan leadership pada anak usia dini lewat pembelajaran, dikarenakan jiwa leadership itu tumbuh karena dibentuk bukan dilahirkan. Leadershipmemerlukan proses belajar sehari-hari lewat pengalaman dan proses pembelajaran dengan pemberian stimulus secara tepat. Untuk memperoleh jiwa leadership yang berkualitas tidak mungkin langsung diperoleh hasil semalam atau dalam waktu singkat.Diperlukan waktu lamadan pengajaran secara konsisten untuk membentuk jiwa leadership padaanak. Dan itu semuadapat dilakukan lewat usia awal-awal perkembangan yakni di usia dini, proses tersebut terjadi terus menerus baik di rumah,sekolah maupun lingkungan sekitar tempat tinggal.

Membekali anak dengan jiwa leadership tidak ada ruginya, khususnya bagi seorang anak yang di daerahnya sudah memiliki tradisi mata pencaharian dalam bentuk kewirausahaan penting disini untuk memiliki jiwa leadership.Pembelajaranleadership tidak hanya untuk orang dewasa tetapi anak-anak pun sudah harus diperatikan, dimana anak-anak sudah mulai ada menyukai sikap yang tidak jujur. Hal ini yang menjadi dasar mengapa sasaran penelitian ini 
adalah anak usia dini yang sedikit banyaknya harus belajartentang jiwaleadership. Dalam hal ini kita akan membahas anak petani garam. Karakteristik petani garam sendiri adalah 1) keras tetapi mudah putus asa (Rochwulaningsih, 2008); 2) sangat tergantung pada alam (Aisyah, et al, 2001); 3) tingginya ketergantungan pada tengkulak; 4) hidupnya didasarkan pada warisan leluhur; 5) secara sosial ekonomi rendah (Hasan, 2011); 6) pendidikan rendah (Hasan, 2011; Izzaty dan Permana, 2011; Manadiyanto dan Nasution, 2011); dan 7) kurangnya ketrampilan dalam menggunakan teknologi baru (Izzaty dan Permana, 2011; Manadiyanto dan Nasution, 2011). Dari karakter tersebut dapat kita gunakan sebagai dasar mengenal petani garam.

Diketahui bahwa sudah sangat jelas, petani garam pasti juga berdagang dan hal ini mau tidak mau pasti akan berlanjut usaha garam secara turun temurun. Hal ini membuat penting untuk mengembangkan entrepreneurial leadership pada anak sejak usia dini khususnya pada anak petani garam yang nantinya dapat melanjutkan usaha keluarga. Tujuannya saat anak sudah memiliki bekal jiwa entrepreneurial leadership, anak akan memiliki keberanian, kemandirian serta ketrampilan, sehingga mampu meminimalisir kegagalan dalam dirinya sehingga tidak mudah putus asa dan terus berjuang serta optimis.

Mengembangkan entrepreneurial leadership pada anak usia dini dalam proses pembelajaran sangatlah mudah, jika stimulus yang diberikan tepat. Hal tersebut terlihat mudah karena terdapat kesesuaian dengan karakteristik yang dimiliki anak usia dini. Selain itu karakteristik dapat dijadikan sebagai bahan acuan dalam pemilihan metode yang tepat dalam pembelajaran. Dalam hal ini pembelajaran anak usia dini tidak jauh-jauh dengan konsep bermain, namun disaat bermain perlu penekanan tentang hikmah atau maksud dari permainan yang dilakukan, sehingga tidak terlihat hanya bermain saja, namun anak bisa belajar banyak hal. Metode pembelajaranfield trip atau dikenal sebagai meode karya wisatadijadikan sebagai alternatif untuk guru menciptakan pembelajaran secara inovatif.Metode field trip ini akan mengajak anak didik datang dan menyaksikan langsung objek yang sedang dipelajari. Dengan melihat langsung obyek yang dipelajari maka pengalaman pun juga apat diperoleh anak didik secara nyata.Fieldtrip merupakan pembelajaran outdoor selain untuk peningkatan aspek-aspek psikologis anak, seperti rasa senang dan rasa kebersamaan yang selanjutnya berdampak terhadap peningkatan perhatian dan motivasi belajar. Dengan kata lain, metode field trip sangat cocok diterapkan sebagai usaha untuk menciptakan pembelajaran yang menarik khususnya mengajakan tentang kewirausahaan di integrasikan dengan pendekatan Design For Change (DFC).

Pendekatan DFC menjadi pilihan untuk anak usia dini karena berkonsep dasar bahwa anak merupakan individu yang memiliki kemampuan untuk membawa perubahan yang luar biasa. Selain itu melalui pendekatan design ini kita sebagai guru maupun orangtua diminta untuk menularkan semangat "saya bisa" yang mana dalam kesempatan ini meminta anak-anak untuk mengekspresikan ide-ide mereka dan meminta untuk menjalankan ide tersebut. DFC didalam bidang pendidikan digunakan untuk mengembangkan ketrampilan yang dibutuhkan oleh anak-anak.Cara kerja pendekatan ini adalah membekali anak dengan sebuah perangkat yang membuat anak lebih peduli terhadap segala informasi.Dalam pendekatan ini tidak hanya bidang akademis yang ditekankan tetapi juga meminta anak-anak untuk peduli secara social dan proaktif dalam menjadi agen perubahan di permasalahan sosial. Maka dari itu penerapan DFC di lingkungan pendidikan diharapkan dalam proses pembelajarannya berfokus mengajarkan anak untuk memiliki sifat antusiasme, kasih sayang, konten, karakter dan berbuat baik.

Desain ini memiliki ketepatan dalam pembelajaran untuk anak usia dini dalam pengembangan kreativitas entrepreneurial leadership. Menurut Kiran Bir Sethi (dalam Eka, 2015) menyatakan bahwa seorang anak harus memiliki FIDS, dalam hal ini disebut sebagai langkahlangkah yakni:

1. Feel (Merasakan)

Dalam langkah ini anak diajak untuk bisa memahami perasaan orang lain dan melihat permasalahan yang ada disekitarnya dengan melalui beberapa tahapan yakni :a) observasi, anak diminta mengamati; b) memilih, dari hasil observasi anak diminta memilih satu kondisi yang ingin dirubah; c) terlibat, mengajak anak untuk belajar mewawancarai orang-orang yang terlibat maupun yang terkena dampak dari keadaan yang ingin dirubah.

2. Image (Membayangkan)

Langkah yang kedua diminta untuk menjadi pemandu dalam mendorong anak untuk dapat mengumpulkan ide sebanyak-banyaknya dan membayangkan solusi yang "tidak 
biasa".Mengajak anak untuk berimajinasi sehingga eksplorasi ide-idenya dapat keluar menakjubkan. Langkah kedua ini jangan beri batasan pada proses penciptaan sebuah ide, tugas kita hanya memandu dan mendorong anak untuk memunculkan bermacam-macam ide.

\section{Do (Melakukan)}

Langkah ketiga saatnya mengajak anak-anak untuk melaksanakan ide-ide yang sudah mereka susun dalam membuat sebuah perubahan. Disini ada beberapa tahap yang harus diperhatikan yakni a) merencanakan cara menjalankan ide; b) mengimplementasikan ide, disini berikan dukungan dan sorakan "Ya Kamu Bisa"; c) Refleksikan yakni mengajak anak untuk dapat mengambil hikmah dari apa yang sudah dilakukan, ajak anak membuat jawaban tentang apa yang telah dipelajari dari diri sendiri lalu bersama temantemannya.

4. Share (Membagikan)

Langkah yang terakhir mengajak anak untuk menularkan atau berbagi kisah lewat cerita dengan orang lain. Dalam langkah ini meminta anak untuk fokus pada F.A.C.T.S yakni

a.Feeling (Perasaan) yakni bagaimana mereka menggambarkan perasaan orang-orang atau teman-teman nya saat bermain tadi

b. Action (aksi) yakni merekam aksi temanteman super mereka saat bermain

c. Changes $\mathcal{E}$ Transformations (perubahan dan transformasi) yakni meminta anak untuk merekam kutipan-kutipan yang bisa membuat seseorang berubah

Jika langkah-langkah diatas dapat dilalui maka permasalahan sosial tentang kewirausahan bisa diatasi secara dini.Desain ini memiliki ketepatan dalam pembelajaran untuk anak usia dini dalam pengembangan entrepreneurial leadership. Ketertarikan peneliti terhadap permasalahan sehingga peneliti mengambil judul "Efektifvitas Metode Pembelajaran Field Trip Pendekatan Dfc Mengembangkan Entrepreneurial Leadership Anak Petani Garam"

\section{METODOLOGI PENELITIAN}

Penelitian ini dilakukan di TK PKK Lembung Pamekasandengan subyek anak Kelompok B usia 5-6 tahun sejumlah 10 anak. Metode penelitian yang digunakan adalah kualitatif dengan pendekatan deskriptif naratif, dengan didasari beberapa alasan, yaitu: (1) bersifat natural, maksudnya adalah penelitian dilakukan sesuai keadaan sebenarnya dan peneliti sebagai instrumen utama, (2) data bersifat deskriptif, (3) lebih menekankan proses daripada hasil, (4) pengolahan data cenderung dilakukan secara induktif, (5) perhatian utama pada setiap aktivitas yang dilakukan individu. Sumber data yakni observasi, wawancara, dan dokumentasi.

Dalam proses analisis adapun alur kegiatan yang akan dilakukan yakni: 1) Reduksi data yakni proses pemilihan, penyederhanaan, pengabstrakan dan transformasi data "kasar" yang muncul dari catatan yang tertulis di lapangan. 2) Penyajian Data yakni sekumpulan informasi yang tersusun memberi kemungkinan adanya penarikan kesimpulan bisa dengan bentuk grafik, maupun bagan.3) Penarikan kesimpulan yakni proses mencari arti, mencatat keteraturan, pola-pola, penjelasan, konfigurasi yang mungkin, alur sebab akibat dan proposisi dari gambaran-gambaran secara keseluruhan baik catatan deskriptif maupun reflektif yang telah dibuat sebelumnya pada bagan.

\section{HASIL DAN PEMBAHASAN}

Pelaksanaan penelitian di TK PKK Lembung Pamekasan terdiri dari tiga tahap adapun penjelasannya sebagai berikut

1. Tahapan observasi awal ke sekolah, dilanjutkan dengan observasi lanjutan penentuan subyek penelitian;

Dalam pelaksanaan sebelum mengambil data peneliti melakukan kunjungan ke Ketua IGTKI Lembung Pamekasan, dilanjutkan observasi awal yang dilakukan ke sekolah pada bulan September 2018. Dalam kegiatan iniyang diamati adalah awal mulai dari aktivitas pembelajaran sampai dengan lingkungan tempat belajar anak.Observasi lanjutan dilakukan dengan cara masuk kelas dan memberikan pembelajaran pada kelompok B sejumlah 15 anak pada bulan September-Oktober 2018. Mengapa dalam penentuan subyek penelitian ditujukan pada anak kelompok B, dengan alasan usia 5-6 tahun sesuai kriteria tahapan perkembangan sudah dianggap mampu untuk menerima instruksi dengan jelas. Dalam kegiatan pembelajaran anak diberikan stimulasi berupa gambar profesi dan aktivitas mata pencaharian masyarakat sekitar sekolah.Pemberian stimulus bentuknya ditambah dengan cerita oleh guru penelitian. Dari 15 anak di kelompok B dipilih menjadi subyek penelitian hanya 10 dengan alasan salah satu kreteria utama yakni anak petani garam, anak mengikuti setiap tahapan pembelajaran dalam penelitian yakni penerapan metode pembelajaran field trip melalui pendekatan design for change guna 
mengembangkan entrepreneurial leadership. Subyek penelitian diantaranya adalah:

Tabel 5.1.2.2 Data Diri Subyek Penelitian

\begin{tabular}{|c|l|c|c|l|}
\hline No & \multicolumn{1}{|c|}{ Nama Murid } & Jenis Kelamin & Umur & \multicolumn{1}{|c|}{ Tempat, Tanggal Lahir } \\
\hline 1 & Anang Bastiar & L & 7 & Pamekasan, 01 Februari 2011 \\
\hline 2 & Avadi Reza Gunawan & L & 6 & Pamekasan, 20 Mei 2012 \\
\hline 3 & Awra Syawqiyah & P & 5 & Pamekasan, 23 September 2013 \\
\hline 4 & Azril Septian & L & 6 & Pamekasan, 01 Septeber 2012 \\
\hline 5 & Gusty Aminullah & L & 5 & Pamekasan, 02 Juli 2013 \\
\hline 6 & Galih Ezakiel Dwi P & P & 6 & Pamekasan, 21Oktober 2012 \\
\hline 7 & Halisa Maulida & L & 6 & Pamekasan, 03 September 2012 \\
\hline 8 & Moh Fayyat Abdullah & L & 5 & Pamekasan, 21 November 2012 \\
\hline 9 & Muhammad Taufik Rafiansyah & L & 6 & Suka Bumi, 28 Juni 2012 \\
\hline 10 & Zakia Alifah Zainuddin & & & \\
\hline
\end{tabular}

2. Tahap pengambilan data yakni penerapan metode pembelajaran field trip melalui pendekatan design for change (DFC), yang disini pelaksanaannya terdapat 4 langkah yakni feel, image, do,dan share. Dalam pelaksanaan penelitian ini sudah berjalan semua ditiap tahapannya

a.Feel (Merasakan)

Dalam langkah ini anak diajak untuk bisa memahami dan melihat aktivitas disekitarnya melalui beberapa tahapan yakni :a) observasi, anak diminta mengamati; b) memilih, anak diminta memilih satu kondisi dari hasil pengamatannya; c) terlibat, mengajak anak untuk belajar terlibat dari keadaan yang di amati

Dalam kondisi ini anak diminta untuk terjun langsung mengamati objek lokasi yang menjadi focus penelitian. Lokasi pembelajaran field trip yang dipilih dalam penelitian ini adalah tambak garam milik juragan besar di Desa Lembung.Pengembangan tema pembelajaran tidak ada setting benarbenar setting alami. Pertama anak dikondisikan diajak untuk berkeliling di daerah tambak sambil dipandu oleh tutor serta dilanjutkan Tanya jawab seputar apa yang sudah diamati. Nampak dari hasil pengamatan siswa antusias dalam kegiatan langkah pertama, memperhatikan di tiap instruksi dan diakhiri memilih kegiatan yang ingin dicoba, disaat proses recalling dilakukan oleh tutor dengan awal pertanyaan.

b. Image (Membayangkan)

Dalam langkah ini anak diminta dapat mengumpulkan ide sebanyak-banyaknya lewat cara berimajinasi. Langkah kedua ini anak tidak diberi batasan pada proses penciptaan sebuah ide, dan peneliti tugasnya hanya memandu dan mendorong anak untuk memunculkan bermacam-macam ide.Pelaksanaannya anak diminta untuk melihat film dengan durasi singkat 15 menit yang diputar sebayak 2 (dua) kali untuk melihat konsistensi sekaligus konsertasinya anak dalam membayangkan ditiap menit kegiatan.Dalam prosesnya anak mampu terinsprasi dilihat dari bukti pengungkapan beberapa subyek ingin seperti pemeran dalam video inspirasi.

c.Do (Melakukan)

Langkah ketiga saatnya mengajak anakanak untuk melaksanakan ide-ide yang sudah mereka susun dalam membuat sebuah perubahan. Ada beberapa tahap yang harus diperhatikan yakni :

1. Merencanakan cara menjalankan ide Dalam tahapan ini anak diminta untuk membuat rencana ide yang ingin dilakukan

2. Mengimplementasikan ide

Ide yang direncanakan coba diimplementasikan lewat sebuah gambar yang akan membentuk sebuah 
alur cerita. Saat proses disini peran tutor sangat berpengaruh yakni memberikan dukungan dan sorakan "Ya Kamu Bisa"

3. Refleksikan

Dari apa yang dihasilkan dalam gambar, siswa menuunjukkan didepan temandan bercerita. Dalam cerita tersebut tutor juga mengajak anak untuk dapat mengambil hikmah dari apa yang sudah dilakukan, dan tutor juga mengajak anak menjawab tentang apa yang telah dipelajari bersama teman-temannya

\section{d. Share}

Anak kembali menceritakan tentang apa yang sudah dirasakan selama waktu pembelajaran dengan cara menggambarkan perasaan teman-teman yang terlibat pula, dilanjutkan dengan aksi pengalaman seru teman-teman selama proses pembelajaran dan terakhir apa perubahan yang dapat diterima atau kaitannya hikamh yang dipelajari selama proses pembelajaran, diikuti dengan harapan impian yang sudah dibentuk.

\section{PEMBAHASAN}

Berdasarkan hasil observasi, wawancara, dan dokumentasi yang dilakukan peneliti selama pelaksanaan penerapan metode pembelajaran field trip melalui pendekatan design for change guna mengembangkan entrepreneurial leadership anak petani garam menyatakan ada beberapa catatan perubahan selama proses. Lokasi penelitian di sekolah dan sekitar sekolah yakni out door saat melakukan metode field trip, intinya menyesuaikan dengan kondisi dalam rancangan penelitian. Akan lebih detail dan jelas jika di tiap langkah kegiatan yang harus dilalui anak kita ketahui yakni anak diminta secara berurutan melakukan kegiatan dalam FIDS lewat metode pembelajaran field trip pendekatan DFC, langkah-langkah yang dimaksud adalah:

1. Feel (Merasakan)

Dalam langkah ini anak diajak untuk berkunjung sekaligus mempelajari kegiatan di suatu tempat yang sudah familiar bagi anak, tujuannya anak bisa semakin memahami dan merasakan dengan dekat kebiasaan alamiah yang sering dijalaninya. Kegiatan ini dikonsep sebagai kegiatan tamasya yakni field trip (tambak garam), dalam kegiatan ini anak diminta untuk dapat melalui beberapa tahapan yakni :

a) Observasi; anak diminta mengamati di tiap kegiatan, mulai dari apa yang dilakukan oleh petani ditambaknya, sampai dengan apa saja alat yang ada ditambak dan kegunaannya. Ada sang juragan yang memandu perjalanan sambil bercerita banyak tentang proses pembuatan garam dan tidak lupa kesuksesan juragan mengelola garam. Dalam proses kegiatan ini anak-anak nampak antusias ditiap proses, nampak dari bagaimana mereka tetap mengikuti aturan dan memperhatikan tutor.

b) Memilih; dari hasil observasi (pengamatan) kegiatan, anak diminta memilih satu dari tiga kondisi yang diceritakan tutor yakni menjadi seorang petani dibayar, pedagang garam, petani yang miliki tambak dan menjual hasil panen sendiri. Dalam wawancara yang dilakukan oleh peneliti pada salah satu anak menyebutkan ingin menjadi "petani yang miliki tambak dan menjual hasil panen sendiri" saat ditanya alasan kenapa memilih itu, si anak menjawab kalau jadi petani dibayar kayak bapak yang digaji hanya 50.000/hari, anak ingin jadi juragan ngumpulin duit banyak dan jadi orang kaya".

c) Terlibat; setelah melihat dan memilih kegiatan, anak diajak untuk belajar membuat sekaligus bertanya-tanya seputar kegiatan kepada istuktur. Dalam proses ini anak sangat senang dan berantusias, nampak dari diikutinya kegiatan hingga akhir.

Pelaksanaan kegiatan langkah pertama ini memakan waktu sekitar 2 jam, dengan hasil anak tidak merasa bosan dan dapat mengikuti kegiatan dengan baik.

2. Image (Membayangkan)

Langkah kedua ini peneliti mengambil lokasi tempat di sekolah.Kegiatan ini lebih banyak dilakukan oleh peneliti yang berperan sebagai pemberi stimulus dan pemandu dalam mendorong anak untuk dapat mengumpulkan ide sebanyak-banyaknya dan membayangkan solusi yang "tidak biasa". Mengajak anak untuk berimajinasi sehingga eksplorasi ide-idenya dapat keluar menakjubkan. Di awal kegiatan peneliti mencoba untuk flash back ulang kegiatan yang sudah dilakukan sebelumnya yakni 
langkah feel dimana kegiatan kemarin mengajak anak berkunjung ke tambak garam. Lalu dilanjutkan dengan stimulus berikutnya berupa pertanyaan dari peneliti yakni siapa yang ingin memiliki tambak besar, anak-anak dengan antusias mengacungkan tangannya.Setelah itu barulah dilanjut pemberian stimulasi berupa pemutaran video inspirasi berjudul "juragan cilik". Video itu bercerita tentang awal mula seorang anak yang sudah memulai karirnya sejak kecil berjualan slime dan akhirnya menjadi juragan cilik yang sukses. Video tersebut berhasil menstimulasi anak-anak untuk ingin menjadi pengusaha, lewat pertanyaan yang mendorong anak-anak untuk bisa jadi juragan cilik. Proses kegiatan ini berlangsung selama 1 jam 30 menit dengan durasi pemutaran video dua kali.

3. Do (Melakukan)

Dalam langkah ini peneliti mengambil lokasi tempat di sekolah.Anak diajak untuk melaksanakan ide-ide yang sudah mereka susun dalam sebuah rencana. Anak harus melalui beberapa tahap yang harus diperhatikan yakni

a) Merencanakan cara menjalankan ide, dalam kegiatan ini anak disediakan buku gambar dan meminta anak untuk menggambar ide yang ingin dilakukan yakni bentuk usaha apa, setelah menggambar anak diminta untuk bercerita kepada peneliti tentang apa yang digambar. Terlihat dari hasil gambar hampir tiap anak memiiki ide usaha hasil stimulasi.

b) Mengimplementasikan ide; dari kegiatan mengambar yang dilakukan anak. Awal kegiatan dimulai dari menyiapkan beberapa media pemanfaatan garam, ada yang memilih pada pembuatan pemanfaatan garam ada yang memilih ke pembuatan gambaran rancangan menjadi petani garam. Tutor hanya bertugas memberi semangat " kamu bisa". Waktu berjalan 20 menit. Kondisi anak sangat antusias menjalankan tiap proses kegiatan. Dalam proses langkah ini selalu diberikan dukungan dan sorakan "Ya Kamu Bisa" itu bagian dari stimulasi

c) Refleksikan; anak diajak untuk dapat mengambil hikmah dari apa yang sudah dilakukan, dan diminta mengungkapkan tentang apa yang telah dipelajari dari mulai diri sendiri, bersama temantemannya, salah satunya bersyukur dari hasil prosesnya. Peneliti masih selalu memberikan dukungan dan sorakan "Ya Kamu Bisa" dan ternyata memang anakanak bisa.

4. Share (Membagikan)

Langkah yang terakhir mengajak anak untuk menularkan semua kegiatan yang sudah dilaluinya dari awal hingga akhir puncak kegiatan dengan bercerita didepan temantemannya. Dalam langkah ini meminta anak untuk tetap fokus pada F.A.C.T.S, dalam kegiatan ini tetap dibantu peneliti untuk mengarahkan yakni dilakukan secara berurutan mulai dari apa yang dirasakan Feeling (Perasaan) yakni anak menceritakan tentang perasaan dirinya saat dibawa ke lokasi tambak, terus impian ingin memiliki perusahaan yang besar dan menceritakan apa yang dirasakannya saat kegiatan begitu senang dan serunya dilanjutkan dengan Action (aksi) yakni merekam aksi temanteman super mereka saat kegiatan, menceritakan ulang teman-temannya. Proses selanjutnya Changes \& Transformations (perubahan dan transformasi) yakni meminta teman-temanya untuk mengikuti instruksi kata-kata sang juragan dengan slogan kata "juragan cilik pasti bisa", dan memberikan pesan pada teman-teman untuk berusaha dan nyakin. Memberi kenyakinan pada teman-temannya bahwa usaha keluarga dapat sukses dtangn kita yakni juragan cilik, meneriakan slogan terakhir " aku bisa, kamu pasti bisa".

Tabel 5.2.1 Hasil Penilaian Subyek Secara Keseluruhan Aspek

\begin{tabular}{|l|c|c|c|c|c|c|c|}
\hline \multirow{2}{*}{ No } & \multirow{2}{*}{ Nama } & \multicolumn{5}{|c|}{ Entrepreneurial Leadership } & \multirow{2}{*}{ Total } \\
\cline { 3 - 7 } & & Kreativitas & Inovasi & Intuisi & Motivasi & $\begin{array}{c}\text { Keberanian } \\
\text { Mengambil }\end{array}$ & \\
\hline
\end{tabular}




\begin{tabular}{|c|l|c|c|c|c|c|c|}
\hline & & & & & & Resiko & \\
\hline 1 & AB & 35 & 15 & 19 & 40 & 30 & 147 \\
\hline 2 & ARG & 31 & 12 & 16 & 34 & 24 & 124 \\
\hline 3 & AS & 18 & 10 & 11 & 24 & 15 & 82 \\
\hline 4 & ASE & 18 & 10 & 11 & 23 & 14 & 80 \\
\hline 5 & GA & 34 & 14 & 17 & 40 & 29 & 141 \\
\hline 6 & GED & 28 & 13 & 16 & 38 & 29 & 131 \\
\hline 7 & HM & 33 & 15 & 18 & 40 & 30 & 143 \\
\hline 8 & MFA & 29 & 13 & 16 & 38 & 29 & 132 \\
\hline 9 & MTR & 20 & 10 & 11 & 29 & 14 & 84 \\
\hline 10 & ZAZ & 20 & 10 & 11 & 25 & 10 & 80 \\
\hline \multicolumn{2}{l|}{ TOTAL } & 295 & 122 & 146 & 326 & 224 & \\
\hline
\end{tabular}

Tabel diatas membuktikan bahwa terdapat 6 anak dari 10 yang memiliki nilai diatas seratus setelah memperoleh beberapa stimulasi. Menunjukkan bahwa di tiap pelaksanaan kegiatan penggunaan metode field trip dengan pendekatan DFC efektif mulai dari langkah feel, image, do \&share. Sedangkan dalam melihat entrepreneurial leadership disaat pembelajaran melalui lima aspek yakni kreatif, inovasi, intuisi, motivasi dan berani mengambil resiko. Dapat ditunjukkan dalam tabel diatas aspek motivasi memberikan sumbangsih terbesar. Untuk melihat lebih detail dari masingmasing aspek pernyataan bagian mana yang memiliki pengaruh tinggi. Data dapat dilihat sebagai berikut:

Tabel 5.2.2 Hasil Observasi Aspek Kreativ Tiap subyek

\begin{tabular}{|c|c|c|c|c|c|c|c|c|c|c|c|c|c|}
\hline \multirow[b]{2}{*}{ No } & \multirow[b]{2}{*}{ Item } & \multirow[b]{2}{*}{ Pernyataan } & \multicolumn{10}{|c|}{ Subyek } & \multirow[b]{2}{*}{$\mathbf{T}$} \\
\hline & & & $\mathbb{B}$ & ฉ & 点 & 点 & $\rho$ & 团 & 3 & 3 & 恣 & $\mathbb{R}_{N}^{N}$ & \\
\hline \multirow{2}{*}{1} & \multirow[t]{2}{*}{$\begin{array}{l}\text { Berfikir } \\
\text { lancar }\end{array}$} & $\begin{array}{l}\text { Anak mampu menghasilkan } \\
\text { gagasan/ide dengan cepat }\end{array}$ & 4 & 4 & 2 & 2 & 4 & 3 & 3 & 3 & 2 & 2 & 29 \\
\hline & & $\begin{array}{l}\text { Anak mampu menjawab } \\
\text { pertanyaan dengan cepat }\end{array}$ & 4 & 3 & 2 & 2 & 4 & 3 & 4 & 3 & 2 & 2 & 29 \\
\hline \multirow{2}{*}{2} & \multirow[t]{2}{*}{$\begin{array}{l}\text { Berfikir } \\
\text { luwes }\end{array}$} & $\begin{array}{l}\text { Anak mampu menghasilkan } \\
\text { gagasan/ide yang bervariasi }\end{array}$ & 4 & 3 & 2 & 2 & 4 & 3 & 4 & 3 & 2 & 2 & 29 \\
\hline & & $\begin{array}{l}\text { Anak mampu memecahkan } \\
\text { masalah }\end{array}$ & 4 & 3 & 2 & 2 & 4 & 3 & 4 & 3 & 2 & 2 & 29 \\
\hline \multirow[t]{2}{*}{3} & \multirow[t]{2}{*}{$\begin{array}{l}\text { Berfikir } \\
\text { orisinil }\end{array}$} & $\begin{array}{lr}\text { Anak mampu membuat } \\
\text { kombinasi-kombinasi } & \text { dari } \\
\text { kegiatan yang sudah ada } & \\
\end{array}$ & 4 & 4 & 2 & 2 & 3 & 3 & 3 & 3 & 2 & 2 & 28 \\
\hline & & $\begin{array}{l}\text { Anak mampu menghasilkan } \\
\text { karya yang berbeda }\end{array}$ & 4 & 3 & 2 & 2 & 3 & 2 & 3 & 2 & 2 & 2 & 25 \\
\hline \multirow{2}{*}{4} & \multirow[t]{2}{*}{ Merinci } & $\begin{array}{l}\text { Anak mampu menjelaskan } \\
\text { gagasan/ide dengan rinci }\end{array}$ & 4 & 4 & 2 & 2 & 4 & 4 & 4 & 4 & 3 & 3 & 34 \\
\hline & & $\begin{array}{l}\text { Anak mampu menghasilkan } \\
\text { karya dengan teliti }\end{array}$ & 3 & 3 & 2 & 2 & 4 & 4 & 4 & 4 & 3 & 3 & 32 \\
\hline \multirow{2}{*}{5} & \multirow[t]{2}{*}{ Menilai } & $\begin{array}{l}\text { Anak mampu mengutarakan } \\
\text { pendapatnya }\end{array}$ & 4 & 4 & 2 & 2 & 4 & 4 & 4 & 4 & 3 & 2 & 33 \\
\hline & & $\begin{array}{l}\text { Anak mampu menentukan } \\
\text { pilihannya secara mandiri }\end{array}$ & 4 & 3 & 2 & 2 & 3 & 3 & 3 & 3 & 2 & 2 & 27 \\
\hline
\end{tabular}

\begin{tabular}{ll}
\hline \multicolumn{1}{l}{ Keterangan: } \\
1 & : Tidak Pernah \\
2 & : Jarang \\
3 & :Sering
\end{tabular}


Jika dilihat pada tabel 5.2.2 dapat dinyatakan bahwa hasil observasi menunjukkan aspek kreatif nilai tertinggi pada item merinci dan menilai.Terbukti dari saat observasi anak sangat sering mengungkapkan pendapatnya tentang gagasan yang ingin dibuat, selain itu anak dapat secara terperinci menjelaskan serta mampu detail memberikan bagian-bagian pada hasil karyanya. Jadi anak dikatakan kreatif saat dia mampu merinci dengan teliti akan gagasan yang ingin dihasilkan serta tidak ragu dalam berpendap. Hal ini nampak saat anak menyampaikan ide dalam sebuah gambar.

Tabel 5.2.3 Hasil Observasi Aspek Inovasi Tiap subyek

\begin{tabular}{|c|c|c|c|c|c|c|c|c|c|c|c|c|c|}
\hline \multirow[b]{2}{*}{ No } & \multirow[b]{2}{*}{ Item } & \multirow[b]{2}{*}{ Pernyataan } & \multicolumn{10}{|c|}{ Subyek } & \multirow[b]{2}{*}{$\mathbf{T}$} \\
\hline & & & $B$ & 党 & b & $\mathbb{P}_{\substack{\infty \\
\text { M }}}$ & P & 田 & $\mathbf{3}$ & \} $&{\text { 䒠 }} &{\begin{array}{l}N \\
N\end{array}} &{ } \\
{\hline \multirow{2}{*}{1}1} &{\multirow[t]{2}{*}{\begin{array}{l}\text { Terbuka pada } \\
\text { perubahan }\end{array}}\begin{array} { l } { \text { Terbuka pada } } \\
{ \text { perubahan } } \end{array}} &{\begin{array}{l}\text { Anak mampu menghasilkan } \\
\text { karya baru dari pendapat orang } \\
\text { lain }\end{array}} &{4} &{4} &{2} &{2} &{4} &{3} &{4} &{4} &{2} &{2} &{31} \\
{\hline} &{ } &{\begin{array}{l}\text { Anak mampu menciptakan hal- } \\
\text { hal baru sesuai keinginannya } \\
\text { sendiri }\end{array}} &{2} &{2} &{2} &{2} &{2} &{2} &{2} &{2} &{2} &{2} &{20} \\
{\hline \multirow[b]{2}{*}{2}2} &{\multirow[t]{2}{*}{\begin{array}{l}\text { Pandangan } \\
\text { peluang }\end{array}}\begin{array} { l } { \text { Pandangan } } \\
{ \text { peluang } } \end{array}} &{\begin{array}{l}\text { Anak mampu mengkreasikan } \\
\text { bahan baru sesuai idenya }\end{array}} &{2} &{2} &{2} &{2} &{2} &{2} &{2} &{2} &{2} &{2} &{20} \\
{\hline} &{ } &{\begin{array}{l}\text { Anak mampu melihat situasi } \\
\text { untuk berkompetisi mencapai } \\
\text { hasil yang memuaskan }\end{array}} &{3} &{2} &{2} &{2} &{3} &{3} &{4} &{3} &{2} &{2} &{26} \\
{\hline \multirow{2}{*}{3}3} &{\multirow[t]{2}{*}{\begin{array}{c}\text { Mimiliki } \\
\text { Perencanaan }\end{array}}\begin{array} { c } { \text { Mimiliki } } \\
{ \text { Perencanaan } } \end{array}} &{\begin{array}{l}\text { Anak mampu menggambarkan } \\
\text { awal rencana impiannya }\end{array}} &{4} &{3} &{2} &{2} &{3} &{3} &{3} &{3} &{2} &{2} &{27} \\
{\hline} &{ } &{\begin{array}{l}\text { Anak menceritkan rencana } \\
\text { sederhana terkait usahanya }\end{array}} &{4} &{3} &{2} &{2} &{4} &{3} &{4} &{3} &{2} &{2} &{29} \\
$\hline
\end{tabular}

\section{Keterangan: \\ 1 : Tidak Pernah \\ 2 : Jarang \\ 3 : :Sering \\ 4 : Sangat Sering}

Jika dilihat pada tabel 5.2.3 dapat dinyatakan pada hasil observasi bahwa anak membutuhkan stimulasi dan dari item yang dominan menyatakan bahwa inovasi anak akan muncul saat anak ditunjukkan suatu kondisi yang nyata akan perubahan, sehingga anak mampu mengembangkan karya baru dari pendapat orang lain. Hal ini tampak setelah ditunjukkan video inspirasi dan ditunjukkan nyata cerita dari sang juragan petani garam. Jadi anak dikatakan dapat memunculkan inovasi saat ada keterbukaan terhadap perubahan.

Tabel 5.2.4 Hasil Observasi Aspek Intuisi Tiap subyek 


\begin{tabular}{|c|c|c|c|c|c|c|c|c|c|c|c|c|}
\hline & & R & 疍 & D & $\mathbb{P}_{\substack{\infty \\
M}}$ & $\bigcap$ & 䍖 & I & 雨 & 帚 & $\begin{array}{l}\mathbf{N} \\
\mathbf{N} \\
\mathbf{N}\end{array}$ & \\
\hline 1 & $\begin{array}{l}\text { Anak mampu meraskan dirinya menjadi } \\
\text { pengusaha }\end{array}$ & 4 & 4 & 2 & 2 & 4 & 4 & 4 & 4 & 2 & 2 & 32 \\
\hline 2 & $\begin{array}{l}\text { Anak mampu menjelaskan gambaran usahanya } \\
\text { secara spontan }\end{array}$ & 3 & 3 & 2 & 2 & 3 & 3 & 3 & 3 & 2 & 2 & 26 \\
\hline 3 & $\begin{array}{l}\text { Anak mampu menghasilkan suatu karya sesuai } \\
\text { kata hatinya }\end{array}$ & 4 & 3 & 3 & 3 & 3 & 3 & 4 & 3 & 3 & 3 & 32 \\
\hline 4 & $\begin{array}{l}\text { Anak mampu mengambil hikmah dari apa yang } \\
\text { sudah dilakukan }\end{array}$ & 4 & 3 & 2 & 2 & 3 & 3 & 3 & 3 & 2 & 2 & 27 \\
\hline 5 & $\begin{array}{l}\text { Anak mampu memberikan kesan tentang apa } \\
\text { yang sudah dipelajari }\end{array}$ & 4 & 3 & 2 & 2 & 4 & 3 & 4 & 3 & 2 & 2 & 29 \\
\hline
\end{tabular}

\section{Keterangan:}

$\begin{array}{ll}1 & \text { : Tidak Pernah } \\ 2 & \text { : Jarang } \\ 3 & \text { : Sering } \\ 4 & \text { : Sangat Sering }\end{array}$

Jika dilihat pada tabel 5.2.4 dapat dinyatakan bahwa hasil observasi menunjukkan aspek Intuisi tampak dominan pada pernyataan anak bisa menghasilkan

karya sesuai kata hatinya berdasarkan pilihan (feel) dan mampu memposisikan dirinya sebagai seorang pengusaha cilik yang sukses (image)

Tabel 5.2.5 Hasil Observasi aspek Motivasi Tiap subyek

\begin{tabular}{|c|c|c|c|c|c|c|c|c|c|c|c|c|c|}
\hline \multirow[b]{2}{*}{ No } & \multirow[b]{2}{*}{ Item } & \multirow[b]{2}{*}{ Pernyataan } & \multicolumn{10}{|c|}{ Subyek } & \multirow[b]{2}{*}{$\mathbf{T}$} \\
\hline & & & $\mathbb{R}$ & Q & is & 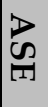 & $\Omega$ & 䍖 & 产 & $\sum_{1}^{3}$ & 寻 & $\mathbb{N}_{\mathbf{N}}^{N}$ & \\
\hline \multirow[t]{2}{*}{1} & \multirow{2}{*}{$\begin{array}{l}\text { Kesenangan, } \\
\text { kenikmatan } \\
\text { untuk belajar }\end{array}$} & $\begin{array}{l}\text { Anak memiliki kemauan dalam } \\
\text { mengikuti kegiatan }\end{array}$ & 4 & 4 & 3 & 3 & 4 & 4 & 4 & 4 & 3 & 3 & 36 \\
\hline & & Anak senang mengikuti kegiatan & 4 & 4 & 3 & 2 & 4 & 4 & 4 & 4 & 3 & 3 & 35 \\
\hline \multirow{2}{*}{2} & \multirow[t]{2}{*}{$\begin{array}{l}\text { Penguasaan } \\
\text { materi }\end{array}$} & $\begin{array}{l}\text { Anak mampu mengungkapkan } \\
\text { kembali kegiatan yang sudah } \\
\text { dipelajari }\end{array}$ & 4 & 3 & 2 & 2 & 4 & 3 & 4 & 3 & 2 & 2 & 36 \\
\hline & & $\begin{array}{l}\text { Anak aktif } \\
\text { berpartisipasi } \\
\text { pembelajaran }\end{array}$ & 4 & 4 & 1 & 1 & 4 & 3 & 4 & 3 & 1 & 1 & 29 \\
\hline \multirow{2}{*}{3} & \multirow{2}{*}{$\begin{array}{l}\text { Dorongan } \\
\text { ingin tahu } \\
\text { kuat }\end{array}$} & $\begin{array}{l}\text { Anak memiliki rasa ingin tahu } \\
\text { yang tinggi }\end{array}$ & 4 & 3 & 1 & 1 & 4 & 4 & 4 & 4 & 1 & 2 & 26 \\
\hline & & $\begin{array}{l}\text { Anak mampu menyelesaikan } \\
\text { kegiatan hingga akhir }\end{array}$ & 4 & 3 & 2 & 2 & 4 & 4 & 4 & 4 & 2 & 2 & 28 \\
\hline \multirow{2}{*}{4} & \multirow{2}{*}{$\begin{array}{l}\text { Keuletan } \\
\text { mengerjakan } \\
\text { tugas }\end{array}$} & $\begin{array}{l}\text { Anak mampu menerima tugas } \\
\text { yang diberikan guru }\end{array}$ & 4 & 3 & 3 & 3 & 4 & 4 & 4 & 4 & 3 & 3 & 31 \\
\hline & & $\begin{array}{l}\text { Anak memiliki kemauan dalam } \\
\text { mengikuti kegiatan }\end{array}$ & 4 & 3 & 3 & 3 & 4 & 4 & 4 & 4 & 3 & 3 & 35 \\
\hline \multirow{2}{*}{5} & \multirow[t]{2}{*}{ Keterlibatan } & $\begin{array}{l}\text { Anak mengikuti proses dan cara } \\
\text { pembuatan kaya }\end{array}$ & 4 & 3 & 3 & 3 & 4 & 4 & 4 & 4 & 3 & 3 & 35 \\
\hline & & $\begin{array}{l}\text { Anak terlibat langsung membuat } \\
\text { karya }\end{array}$ & 4 & 4 & 3 & 3 & 4 & 4 & 4 & 4 & 3 & 3 & 35 \\
\hline
\end{tabular}

\section{Keterangan:}

1 : Tidak Pernah 


$$
\begin{array}{ll}
2 & \text { : Jarang } \\
3 & \text { : Sering } \\
4 & \text { : Sangat Sering }
\end{array}
$$

Jika dilihat pada tabel 5.2.5 dapat dinyatakan bahwa hasil observasi menunjukkan ke lima pernyataan terdapat empat pernyataan yang muncul. Pernyataan pertama senang dalam menikmati pembelajaran pada item memiliki kemauan mengikuti kegiatan dan senang mengikuti kegiatan; pernyataan kedua yakni keterlibatan pada item anak menikmati tiap proses membuat sebuah karya dan ikut terlibat di tiap pembuatan karya; pernyataan ketiga yaitu penguasaan materi pada item anak mampumenceritakan kembali hasil kegiatan yang sudah dipelajari; dan pernyataan keempat yatu ulet dalam mengrjakan tugas pada item anak mmiliki

\begin{tabular}{|c|c|c|c|c|c|c|c|c|c|c|c|c|c|}
\hline \multirow[b]{2}{*}{ No } & \multirow[b]{2}{*}{ Item } & \multirow[b]{2}{*}{ Pernyataan } & \multicolumn{10}{|c|}{ Subyek } & \multirow[b]{2}{*}{$\mathrm{T}$} \\
\hline & & & $\mathbb{w}$ & 芴 & b & 点 & $>$ & A & $\frac{\pi}{3}$ & 市 &  & $\mathbb{R}_{\mathbf{N}}^{N}$ & \\
\hline \multirow{2}{*}{1} & \multirow{2}{*}{$\begin{array}{l}\text { Berani tanya } \\
\text { dan ditanya }\end{array}$} & Anak mampu bertanya & 4 & 3 & 1 & 1 & 4 & 3 & 4 & 3 & 1 & 1 & 25 \\
\hline & & Anak berani menjawab & 4 & 3 & 1 & 1 & 4 & 3 & 4 & 4 & 1 & 1 & 26 \\
\hline \multirow[b]{2}{*}{2} & \multirow{2}{*}{$\begin{array}{l}\text { Rasa percaya } \\
\text { diri }\end{array}$} & Anak tampil kedepan & 4 & 3 & 1 & 1 & 3 & 4 & 4 & 4 & 2 & 1 & 27 \\
\hline & & $\begin{array}{l}\text { Anak mampu menujukan hasil } \\
\text { karya }\end{array}$ & 4 & 3 & 2 & 2 & 4 & 4 & 4 & 3 & 2 & 1 & 29 \\
\hline \multirow{2}{*}{3} & \multirow[t]{2}{*}{$\begin{array}{l}\text { Berani } \\
\text { mencoba }\end{array}$} & $\begin{array}{l}\text { Anak mampu menerima kegiatan } \\
\text { yang sulit }\end{array}$ & 3 & 3 & 2 & 2 & 4 & 4 & 3 & 4 & 2 & 1 & 28 \\
\hline & & $\begin{array}{l}\text { Anak berani mencoba hal-hal } \\
\text { baru }\end{array}$ & 3 & 3 & 2 & 2 & 4 & 4 & 3 & 3 & 2 & 1 & 27 \\
\hline \multirow[t]{2}{*}{4} & \multirow{2}{*}{$\begin{array}{l}\text { Kemauan } \\
\text { bertanya } \\
\text { dalam } \\
\text { meminta } \\
\text { bantuan }\end{array}$} & $\begin{array}{l}\text { Anak berani meminta bantuan } \\
\text { pada teman saat mengalami } \\
\text { kesulitan selama kegiatan }\end{array}$ & 4 & 3 & 3 & 2 & 3 & 4 & 4 & 4 & 3 & 2 & 32 \\
\hline & & $\begin{array}{l}\text { Anak meminta bantuan pada } \\
\text { guru ketika tidak paham materi }\end{array}$ & 4 & 3 & 3 & 3 & 3 & 3 & 4 & 4 & 1 & 2 & 30 \\
\hline
\end{tabular}
kemauan di tiap kegiatan.

Tabel 5.2.6 Hasil Observasi Aspek Berani Ambil Resiko Tiap subyek

\begin{tabular}{ll}
\hline Keterangan: \\
1 & : Tidak Pernah \\
2 & : Jarang \\
3 & : Sering \\
4 & : Sangat Sering
\end{tabular}

Jika dilihat pada tabel 5.2.6 dapat dinyatakan bahwa hasil observasi menunjukkan aspek Berani Ambil Resiko nilai tertinggi pada item kemampuan bertanya dalam meminta bantuan dan rasa percaya diri. Terbukti bahwa dari sepuluh subyek terdapat enam sudah hamper mencapai penilaian sering muncul disaat pembelajaran. Jadi anak mampu menunjukkan sikap berani mengambil resiko saat ada kemampuan bertanya dalam meminta bantuan yang dimaksud adalah anak meminta bantuan guru ketika tidak paham materi kegiatan berwirausaha dan memiliki rasa percaya diri dibuktikan dengan mampu menunjukkan hasil karya.Selain itu yang menjadi catatan anak sadar bahwa dalam pembelajaran kewirausahaan ini ada kompetisi, sehingga secara mandiri anak mencoba untuk tidak meminta bantuan pada teman saat dirinya mengalami kesulitan.

\section{KESIMPULAN}

Berdasarkan hasil penelitian diatas maka dapat disimpulkan Penerapan metode pembelajaran field trip pendekatan Design for Change (DFC)sangat efektif dalam mengembangkan entrepreneurial leadership, nampak disetiap langkah pelaksanaan mulai dari feel, image, do dan share subyek mengalami peningkatan. Sedangkan yang dimaksud sebagai entrepreneurial leadership pada anak usia dini saat memiliki karakteristik antara lain : a) motivasi yakni memiliki keterlibatan yang tinggi terhadap tugas dan senang sekaligus menikmati ditiap kegiatan belajar dan; b) kreativ 
yakni mampu berfikir lancar dan berfikir luwes.

\section{DAFTAR PUSTAKA}

Abimanyu, S., dkk. 2008. Strategi Pembelajaran. Jakarta: Direktorat JendralPendidikan Tinggi Departemen Pendidikan Nasional.

Adiraga, Y. 2013. Analisis Dampak Perubahan Curah Hujan, Luas Tambak Garam dan Jumlah Petani Garam Terhadap Produksi Usaha Garam Rakyat di Kecamatan Juwana Kabupaten Pati (Periode 2003-2012). Skripsi.Semarang :Fakultas Ekonomi dan Bisnis, Universitas Diponegoro

Aqib, Z. 2014. Model-model, Media, dan Strategi Pembelajaran Kontekstual (novati).Bandung: Yrama Widya.

Batic, J. 2011.The Field Trip as Part of Spatial (Architectural) Design Art Classes. Onlinewww.dlib.si.pdf diakses tanggal 21 April 2018

Djamarah, S., B. 2006.Guru dan Anak Didik dalam Interaksi Edukatif.Jakarta: Rineka Cipta.

Eka, S., N. 2015. Aku Bisa! Inspirasi dari Gerakan Design for Change oleh Kiran Bir Sethi.Jakarta: Noura Books.

Fitroh, S., F \& Mayangsari, D. 2017. Efektifitas Pembelajaran Pendekatan Design For Change Dalam Pengembangan Kreativitas Entrepreneurial Leadership Anak Usia Dini. Proseding Senaspro, hal 804-812.

Fitroh, S., F \& Mayangsari, D. 2017. Kreativitas Entrepreneurial Leadership Dalam Pembelajaran Kewirausahaan Pada Anak Usia Dini. Jurnal Pendidikan Anak Vol 6 (2) hal 171-180.

Hamdayana, J. 2014. Model dan Metode Pembelajaran Kreatif.Jakarta : Ghalia Indonesia.

Hartati, S. 2005. Perkembangan Belajar Pada Anak Usia Dini. Depdiknas.

Hasan, T., I., B. 2011.Identifikasi Sosial Ekonomi dan Ketenagakerjaan Petani Garam di Kabupaten Bireuen.Jurnal Sains Riset, Vol 1 (2)

Hidayah, C. 2014. Pengembangan Kreativitas Anak Usia Dini Berbasis Pendidikan Tauhid Dan Entrepreneurship (Penelitian di TK Khalifah Gedong Kuning Yogyakarta). Tesis.Yogyakarta: Program Pascasarjana UIN Sunan Kalijaga

Majid, A. 2014.Pembelajaran Tematik Terpadu. Bandung: PT Remaja Rosdakarya.

Nebit, S., \& Mayer, A . 2010. The Influence or Field Trip Experiences on Student Beliefs. Transformative Dialogues: Teaching $\mathcal{E}$ Learning
Journal, Vol 4(2) hal 1-22.

Rachman, A. 2011.Evaluasi Kinerja Usaha Petani Garam Rakyat (Studi Kasus di Kabupaten Bima, Nusa Tenara Barat).Tesis.Bogor : Institut Pertanian Bogor

Rahman, H., S.. 2002. Konsep Dasar Pendidikan Anak Usia Dini. Yogyakarta: Galah.

Rochwulaningsih, Y., S. 2008. Petani Garam dalam Jeratan Kapitalism: Analisis Kasus Petani Garam di Remban, Jawa Tengah. Jurnal Masyarakat, Kebudayaa dan Politik, Vol 20 (3). (online)

http://journal.unair.ac.id/detail_jurnal.php? $\mathrm{id}=2153 \&$ med $=15 \& \mathrm{bid}=8>$. Diakses tanggal 25 Juni 2018

Sagala, S. 2006. Konsep dan Makna Pembelajran.Bandung : Alfabeta.

Sudjana, N. 2010.Dasar-dasar Proses Belajar. Bandung: Sinar Baru

Sugianto., E., Y \& Sutanto., E., M. 2013. Pengaruh EntrepreneurialLeadership Terhadap Iklim Organisasional, Kreativitas, Dan Inovasi Karyawan Bagian Produksi Pada Sbo TV. Jurnal AGORA, Vol 1 (2) Hal 1-9.

Susanto, A. 2015.Teori Belajar Da Pembelajaran Disekolah Dasar.Jakarta: Prenata Media

Wang, H., \& Carlson, S., P. 2011. Factors that Influence Student's Satisfaction in an Environmental Field Day Experience.International Electronic Journal of Environmental Education, Vol. 1 (2).Online. Tersedia di http://www.iejeegreen.com/index.php/ieje egreen/article/view diakses tanggal $24 \mathrm{Mei}$ 2018

Yati, P. 2016. Pendidikan Anak Usia Dini Melalui Metode Field Trip untuk Menanamkan Karakter Pada Anak Usia Dini. Lentera Vol XVIII (1), hal 123-139.

Yulianti, D. 2010. Bermain Sambil Belajar Sains di Taman Kanak-kanak. Jakarta: PT Indeks 